\title{
Hunting by Early Modern Lule Sami Households
}

\author{
Jesper Larsson ${ }^{1,2}$ and Eva-Lotta Päiviö Sjaunja ${ }^{1}$
}

(Received 5 January 2021; accepted in revised form 22 March 2021)

\begin{abstract}
Hunting was one of three pillars, along with fishing and reindeer husbandry in the early modern Sami economy, and understanding of Sami hunting has increased during recent decades. However, most research has concentrated on time periods before AD 1600. After AD 1600 and the initial formation of modern Nordic countries, hunting ceased to be the backbone of the overall Sami economy but continued as an integral part of household economies. Our aim is to advance understanding of early modern hunting in northwestern interior Fennoscandia. Using source materials including court rulings and historical accounts, we set out from a self-governance perspective focusing on how actors solved resource distribution with regards to hunting. We show that ecological differences between mountains and forest impacted decisions about hunting. From the $1500 \mathrm{~s}$ to the end of the 1700s, hunting led to the extinction of wild reindeer and depopulation of fur animals, while small-game hunting for subsistence continued to be important. In the forest region, strong property rights to game developed when skatteland (tax land) was established and hunting became a private enterprise. We suggest that the institution of skatteland was a response to changes in Sami economy, and the transition from collective to individual hunting was a contributing factor.
\end{abstract}

Key words: Sami; hunting; early modern; wild reindeer; self-governance; small game; Scandinavia; skatteland (tax land); social justice; household

RÉSUMÉ. Avec la pêche et l'élevage des rennes, la chasse constitue l'un des trois piliers des débuts de l'économie moderne des Samis, et l'activité de la chasse par les Samis fait l'objet d'une meilleure compréhension depuis quelques décennies. Cependant, la plupart des recherches sont concentrées sur les périodes précédant 1600 A.D. Après 1600 A.D. et la formation initiale des pays nordiques modernes, la chasse a cessé de représenter la clé de voûte de l'économie générale des Samis, mais elle a continué de faire partie intégrante des économies domestiques. Notre objectif consiste à mieux comprendre les débuts de la chasse moderne dans le nord-ouest de l'intérieur de la Fennoscandie. À l'aide de sources diverses, dont des décisions judiciaires et des récits historiques, nous sommes partis d'une perspective d'autogouvernance mettant l'accent sur la façon dont les acteurs réglaient la répartition des ressources en matière de chasse. Nous montrons que les différences écologiques entre les montagnes et la forêt exerçaient une influence sur les décisions de chasse. Des années 1500 à la fin des années 1700, la chasse a mené à la disparition du renne sauvage et au dépeuplement des animaux à fourrure. Pendant ce temps, la chasse de subsistance au petit gibier a continué à revêtir de l'importance. Dans la région forestière, de solides droits de propriété du gibier se sont formés lorsque le skatteland (impôt foncier) a été mis en place et que la chasse est devenue une entreprise privée. Nous suggérons que la mise en vigueur du skatteland s'est faite en réponse aux changements caractérisant l'économie des Samis, et que la transition de la chasse collective à la chasse individuelle a été un facteur contributif.

Mots clés : Sami; chasse; débuts de la période moderne; renne sauvage; autogouvernance; petit gibier; Scandinavie; skatteland (impôt foncier); justice sociale; ménage

Traduit pour la revue Arctic par Nicole Giguère.

\section{INTRODUCTION}

Hunting was one of three pillars in the early modern Sami economy, which mostly was based on the use of natural resources. The other pillars were fishing and reindeer husbandry. While previous research has addressed multiple aspects of early modern Sami fishing and reindeer husbandry, the focus on hunting has been relatively constricted (Josefsson et al., 2010; Bjørklund, 2013; Norstedt et al., 2014), partly because of the relative scarcity of hunting evidence in historical sources.
Until the 1970s, Sami historiography was characterized by ethnographic perspectives (Tanner, 1929; Tegengren, 1952; Manker, 1960; Fjellström, 1962; Hvarfner, 1965; Henriksson, 1978). Since the 1980s, scholars in archeology and history have worked intensely to write Sami history. Over the past four decades, the understanding of Sami hunting has increased vastly by highlighting the role of hunting in Sami society and its impact on Sami relations with neighbouring people. However, most researchers have concentrated on time periods before 1600 , which is about the time hunting ceased to be the backbone of Sami economy

\footnotetext{
${ }^{1}$ Department of Urban and Rural Development, Swedish University of Agricultural Sciences, Box 7012, 75007 Uppsala, Sweden

${ }^{2}$ Corresponding author: jesper.larsson@slu.se

(c) The Arctic Institute of North America
} 
(Lundmark, 1982:170; Hansen and Olsen, 2014:230). One of the most intense debates among these scholars has revolved around the question of when, why, and how Sami society transitioned from hunting to herding, but the changes in herding were the overriding factors (Sommerseth, 2011; Bergman et al., 2013). The focus on herding has somewhat overshadowed how hunting continued to be an integral part of a more complex household economy for many Sami long after the introduction of large-scale reindeer husbandry (Bjørklund, 2013; Päiviö, 2017). Therefore, for the early modern period, the ethnographic descriptions of hunting dominate the literature (Hvarfner, 1965; Fjellström, 1986; Kjellström, 2000).

Although Sami hunting lost importance in international trading around 1600 (Hansen and Olsen, 2014:230), it played a vital role in many Sami households in the 17th and 18th centuries (Bjørklund, 2013; Päiviö, 2017). This circumstance stands out in many contemporary sources, where the topic of hunting frequently appears. Our aim is to analyze early modern Sami hunting from a household perspective and to advance beyond descriptions of particular practices toward a more systematic understanding of early modern hunting in interior northern Sweden. In this approach, we used an analytic framework with information from contemporary sources, chiefly written accounts and court rulings.

To broaden the understanding of early modern Sami hunting, we begin from a self-governance perspective using the social-ecological systems (SES) framework, which describes how actors interact with natural conditions and governing systems in a process that constantly redefines the systems they live in (Ostrom, 2009; McGinnis and Ostrom, 2014). Hunters depend on common-pool resources (CPRs) and maintaining equity and ensuring household subsistence rules within users' rights to resources are essential. To achieve our goal, we pose the following questions: How did ecological settings-alpine region, boreal forest, and accessible game-impact the households' hunting strategies? What sort of game was hunted and what was the purpose of the hunts? Who had the right to hunt, and what kinds of hunting grounds did users have access to? Was hunting performed as collective action or was it a private enterprise? How important was hunting for a household? And how did these variables change? By answering these questions, we have broadened the discussion about early modern hunting to include more economic, legal, and social aspects in relation to the household. Our source materials are from the mid-17th century to 1780 , but by including secondary sources, we can discuss some changes in hunting from the mid-16th century.

\section{BACKGROUND}

Hunting is the practice of pursuing, capturing, or killing wildlife and can be divided into subsistence, commercial, and recreational hunting (Peterson, 2019). It has been of paramount importance for the Sami economy, especially until circa 1600. To understand how hunting has been portrayed, one has to look into Sami historiography. According to Hansen and Olsen (2014:2), "the Sami past did not belong to the academic responsibilities of the historical disciplines" until the 1970s. Scholars had up to then approached the Sami past from an ethnographic perspective and portrayed them as belonging to a homogeneous and relatively fixed culture. In contrast to the majority populations in Western countries, Indigenous peoples were seen as groups of people who lacked their own history. Hence, hunting was portrayed as static (Tanner, 1929; Tegengren, 1952; Manker, 1960; Fjellström, 1962; Hvarfner, 1965). From the 1980s, archeologists and historians became involved in making the Sami visible as historical subjects, which included a scholarly interest in hunting, especially by archeologists.

Scholars studying prehistoric and medieval Sami hunting in a wider geographical area have been concerned with four main themes. The first theme deals with how wild reindeer became the most important animal to hunt, why mobile settlements were required, and how large pitfall-trapping systems were established (Mulk, 1994; Vorren, 1998; Sommerseth, 2009). The second theme deals with the fur trade and how high-quality furs harvested by Sami were the most important factor in the establishment of the northern trade networks during the Viking Age and Early Middle Ages (Odner, 1983; Hansen, 1990; Hansen and Olsen, 2014:127-131). The third theme deals with collective hunting, for which researchers have focused on pitfall hunting until circa 1600 (Tegengren, 1952; Vorren, 1978; Mulk, 1994; Sommerseth, 2011). Their empirical findings were underpinned by Ingold's (1980) theoretical work. The fourth theme deals with hunting rituals and ceremonies, and scholars have shown that there was a strong link between religion and hunting in societies that depended on hunting (Korhonen, 2007; Rydving, 2010; Hansen and Olsen, 2014). Beyond these themes, there are other aspects of pre-early modern hunting. For example, small-game hunting must have been common, but a lack of sources has made it difficult to analyze.

Hunting has been regarded as an important factor behind the formation of Sami ethnicity (Odner, 1983). Scholars have argued that Sami ethnicity in northern Fennoscandia emerged as a result of the interaction between hunting populations and surrounding agrarian societies (Hansen and Olsen, 2014:22-23). An elaborate trade system developed between hunters in the north and traders and producers in the east and south. Hunting was an economic specialization that made the Sami dependent on trade (Odner, 1983; Hansen, 1990; Hansen and Olsen, 2014:127-131).

Around the beginning of the 17th century, Sami society went through several major changes: the number of wild reindeer was decreasing, and the use of pitfall hunting declined rapidly (Lundmark, 1982; Mulk, 1994). In many households, reindeer herding replaced fur hunting and gradually became the backbone of the economy. Scholars 
who focused on the early modern era thus had less interest in analyzing hunting as a collective enterprise. We conclude that when hunting no longer played an important part in the research definition of Sami ethnicity, it became less interesting for scholars. Instead, the study of Sami ethnicity and research on early modern Sami history have focused mostly on reindeer herding and Sami relations to the state (Hultblad, 1968; Arell, 1977; Lundmark, 1982, 2006; Kvist, 1989; Sommerseth, 2011). Much of our little knowledge about early modern Sami hunting still comes from ethnographic literature.

The ethnographic analyses have nevertheless contributed greatly to our understanding of Sami hunting, especially when it comes to small game. They contain detailed descriptions of how hunting was performed, which hunting methods were used, the seasonality of hunting, and types of hunting gear. Pre-20th-century Sami practices are often portrayed as rather static (Tanner, 1929; Tegengren, 1952; Manker, 1960; Henriksson, 1978; Fjellström, 1986; Kjellström, 2000).

The transition from a hunter-gatherer economy to a pastoral economy has continued to draw the attention of archeologists and historians, but the primary focus has been on reindeer husbandry, not on hunting. Two papers published in 2013 came to very different conclusions about the introduction of reindeer pastoralism. Bergman et al. (2013) used archeological traces of so-called stállo foundations (the arrangement of Sami community structures) as a proxy for reindeer nomadism and argue that the shift started as early as AD 800. In contrast, Bjørklund (2013:186) argued that after 1750 users started to have reindeer herds large enough to make a living and that there was "no paradigmatic abrupt change through domestication from a 'hunting society' to a 'pastoral society." Bjørklund believes that hunting was part of human adaption to the environment up to the 19th century. Hunting is elusive in the empirical parts of both these papers.

Päiviö (2017) took an approach similar to Bjørklund's when she discussed hunting as part of the household economy. To understand that economy, she argued, one has to include hunting in addition to reindeer herding, fishing, gathering, handicrafts, trade, and transport. She used early modern accounts as sources and applied a broad description of hunting, also used in this article, to include grabbing, trapping, pursuing, and tracking.

Research that has analyzed human adaptations to early modern environmental settings in interior northern Sweden mentions hunting in general terms but gives few details about methods and prey. Josefsson et al. (2010:147), for example, estimated the number of people that a particular territory could support and provided a short list of animals that were hunted for fur. Norstedt et al. (2014) quantified the resources controlled by households in the Ume Sami region. According to their results, fishing was the only resource that showed any correlation to taxation, underscoring the importance of fishing in the forest region. However, in their study, hunting comprised only an estimation of the number of wild reindeer in the region. At that time wild reindeer were in decline, but more important, the study downplayed the significance of other hunted animals including small game, which are mentioned in the sources (Norstedt, 2011).

\section{Methods and Sources}

We used source materials that touch upon early modern hunting from all Swedish lappmarks (regions), except Kemi in present-day Finland (Fig. 1) and concentrated on Lule lappmark as an example to get more detailed information. In Lule lappmark, early modern Sami had access to hunting grounds in both the boreal forest and the alpine zone. From the mid-17th century, Lule lappmark was divided into five villages (Fig. 2). All Sami lived in these villages, which were fairly large districts and social communities.

The focus on Lule lappmark was motivated by very useful court rulings from Häradsrätten (the local court) in Jokkmokk and detailed accounts (Högström, 1747; Rheen, 1897). Court rulings from the same region and time period have been used in two recent articles about Sami culture (Larsson and Päiviö Sjaunja, 2020a, b). We refer interested readers to these publications and their cited references for critical considerations as well as in-depth discussions of the role of the local court. Here we present a brief overview of how we used the court cases.

In the 18th century, it was very common for local users to take their disputes over natural resources to court. Hultblad (1968) published short extracts of court rulings from Jokkmokk's parish, which includes the villages of Sirkas, Tuorpon, Sjokksjokk, and Jokkmokk in Lule lappmark. Between 1700 and 1780, about 270 cases concerned land use. About $70 \%$ of these cases dealt with reindeer grazing or with access to land in more general terms, around $24 \%$ dealt with fishing, and only $6 \%$ dealt explicitly with hunting. These proportions suggest that users were concerned mostly with the expanding reindeer herding during the 18th century, and conflicts over hunting rarely were taken to court. However, the percentages say less about what role hunting played in the household than the cases themselves. Although there are relatively few hunting cases in the court material, the ones that exist have provided detailed information. We used Hultblad's (1968) excerpts to find cases that dealt with hunting, then turned to the original sources to get more meticulous descriptions of the cases. In addition, some court rulings mentioned hunting in passing, although they mainly dealt with another type of conflict (e.g. theft, assault). Information from such cases almost doubled the number of hunting cases to include 30 rulings from Lule lappmark, all of which we retrieved from the original records. A few cases involved people from Kaitum Sami village. Kaitum and the northern part of Sjokkjokk were formed in 1742 from Gällivare parish in Lule lappmark; in 1751, Kaitum got its own local court. Court rulings regarding hunting from other districts were published, and some of them have been used to contrast or corroborate evidence from Lule lappmark (Arell, 1977; Korpijaakko-Labba, 1994; Korhonen, 2007). 


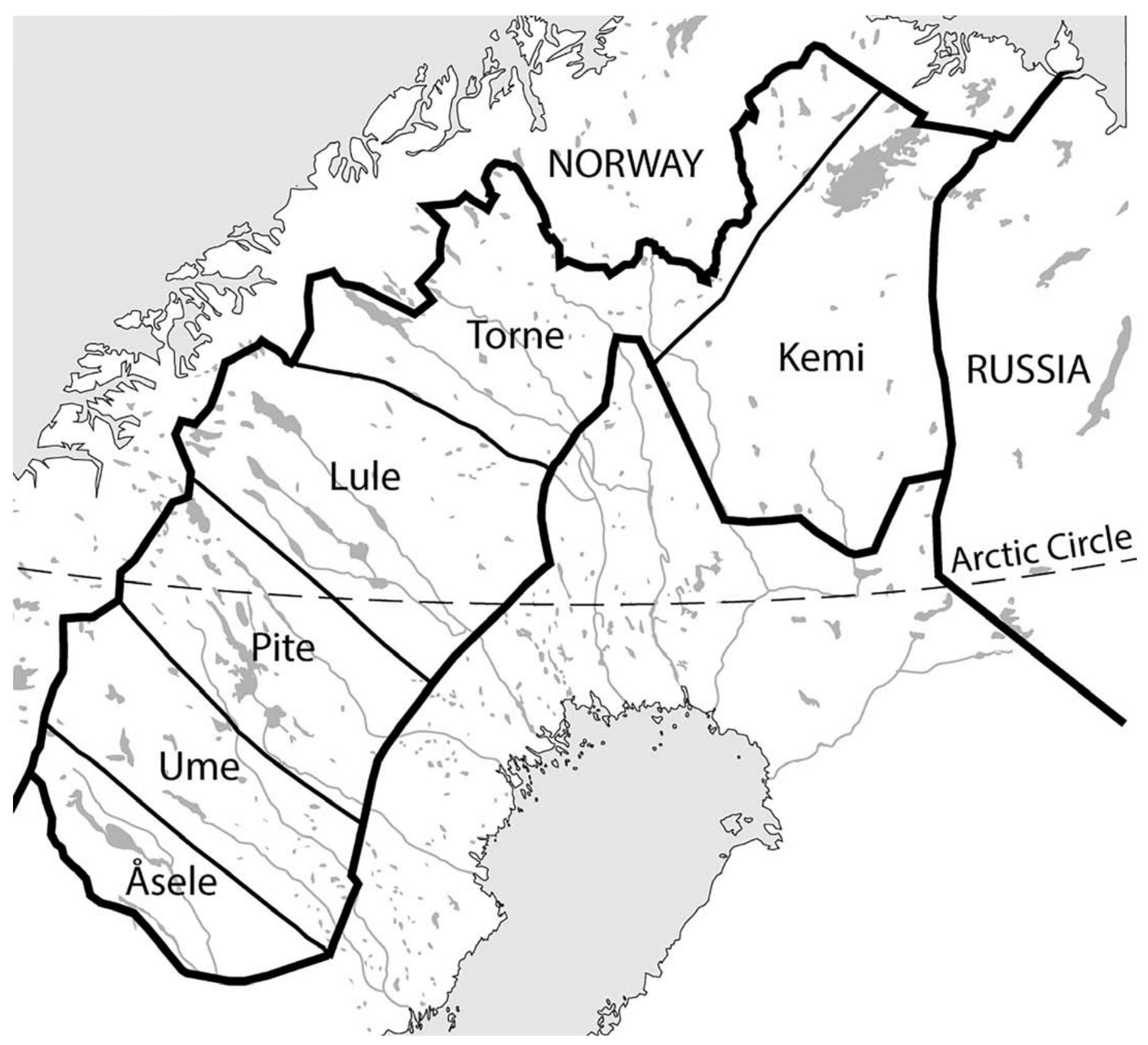

FIG. 1. The Swedish lappmark in the 18th century. Adapted from Charta öfver Wästerbotten och Svenske Lappmarcken (https://commons.wikimedia.org/wiki/ File:Västerbottens_län_och_svenska_lappmarken_1796.svg).

We also studied written accounts about Lule lappmark and other parts of northwestern interior Fennoscandia that describe hunting in Sami settings. Like most Indigenous people, Sami produced virtually no written sources of their own before the 19th century. In order to describe hunting and hunting rights in Lule lappmark in the 17th and 18th centuries, we relied on court documents and accounts produced for various purposes by outsiders. Most accounts were written by Swedish priests and travelers to the region, who stayed for long or short periods of time and had fairly close contacts with the inhabitants. These outsiders often provided detailed insights into Sami life and customs. Only one account was compiled by an author recognized as Sami (Lundius, 1905:3).
Unlike reindeer husbandry, hunting was described with few words and almost in passing in many of the accounts. Fishing also was barely described but more elaborately than hunting (Larsson and Päiviö Sjaunja, 2020b). Bear hunting was more meticulously described, probably because it was connected to ceremonies that the authors found fascinating. Given the irregular and seasonal nature of hunting, authors who paid only short visits to local households seldom had the opportunity to take part in hunts, particularly for large game. It is therefore doubtful whether they actually witnessed the procedures they described, and it is more likely that their reports were based on hearsay and retelling of hunting stories. For the narrator, it was probably both easy and tempting to choose a spectacular story instead of 


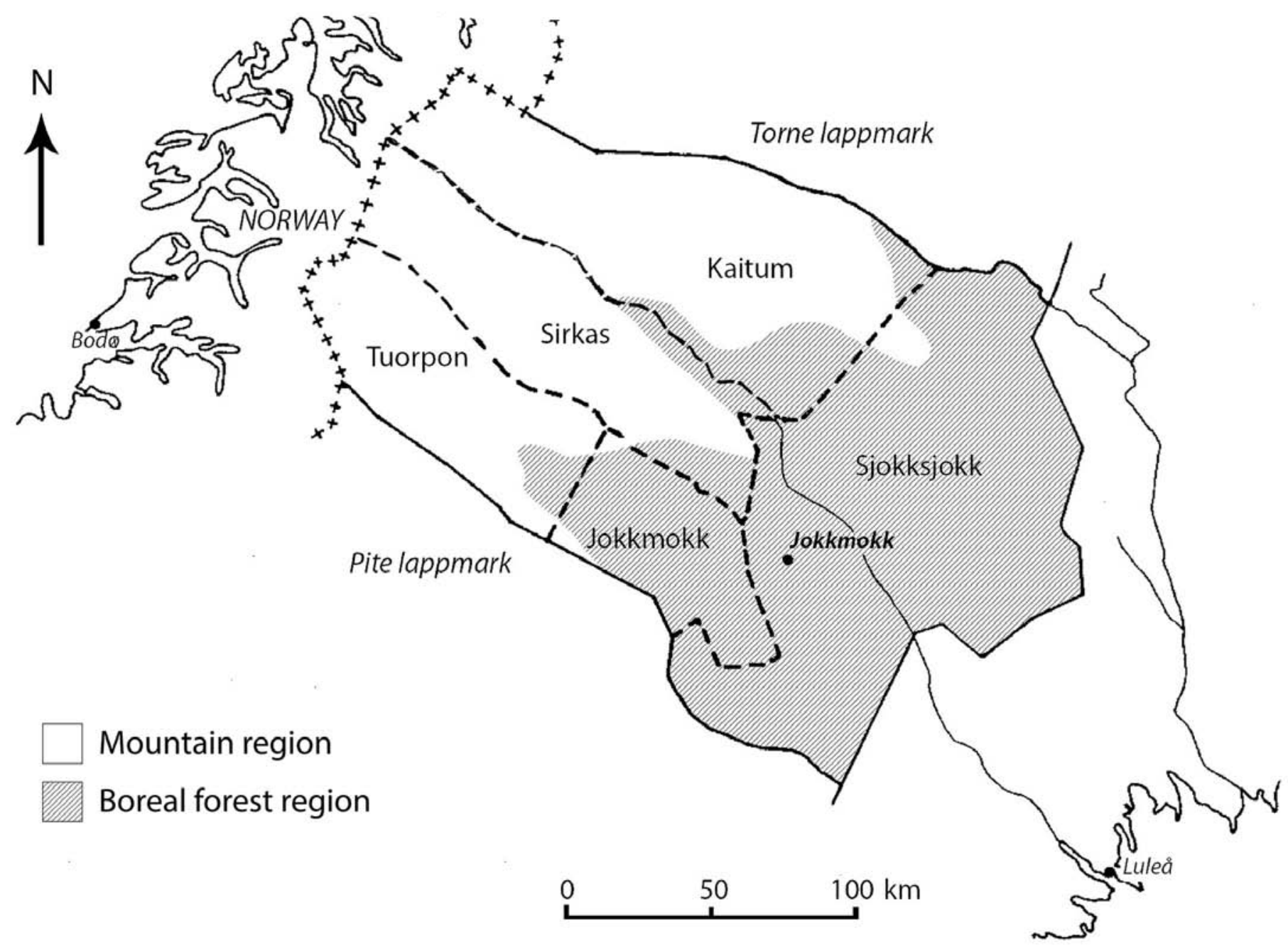

FIG. 2. Map of Lule lappmark circa 1760, showing borders between Sami villages Sjokksjokk, Jokkmokk, Tuorpon, Sirkas, and Kaitum. Adapted from Kvist (1989:16) and Jansson (2011:34-35).

a more typical one. Hence, it is possible that the accounts give us a slightly embellished picture of hunting.

It is plausible that the visitors actually witnessed some of the small-game hunting, which was done more frequently and in the vicinity of the living grounds (a term used to describe areas where Sami establish camp). For example, Linnaeus (2003:62) described that he had seen traps for capercaillies everywhere when he traveled in Ume lappmark in 1732. Other trapping devices that must have been easily recognizable for visitors were bird houses used for gathering eggs, as well as snaring devices for various land fowl, which are commonly mentioned in the accounts.

The anecdotal hunting descriptions make it difficult to systematically assess if a certain hunting practice was common or to what degree a prey contributed to a household's economy. To try to compensate for the risk of exaggerating sketchy evidence, we have compared accounts describing Sami hunting from several parts of northern interior Sweden and combined the information with evidence in the court rulings.

A more systematic approach can be seen in Anders Holm's account that is part of a map drawn by surveyor
Jonas Gedda covering Ume lappmark in 1671 and published by Norstedt (2011). The map is subdivided into 37 skatteland (tax lands), and Holm's account describes available resources on each portion of land including game for hunting, but he does not mention hunting methods.

\section{Self-Governance}

Hunting is an interaction with nature and can thus be described as part of a social-ecological system. To catch or trap animals, users must have access to land and water. Hence, hunting can be analyzed as the use of CPRs. What characterizes a CPR is that it is difficult but not impossible to exclude other users, and that the catch is subtractable (Ostrom, 2005). Once an animal is caught, it cannot be hunted by someone else, and there is potential for overuse. Sustainable hunting, which provides a livelihood today and for coming generations, requires institutions with rules that in different ways control the users' access to hunting grounds. These rules stipulate, for example, who has access, when someone has access, withdrawal amounts, and punishments for violations of rules (Ostrom, 1990, 
2005). A special challenge in regard to hunting regulations is that animals wander in the landscape and can move between areas with detailed regulations and areas with few or no regulations. Rules for early modern hunting ranged from extreme control to total lack of control, or open access. A user's right to prey could be linked either to his or her control over the area where the animal was killed or to the effort he or she put into the hunt. The issue of who possesses the game has been widely discussed by users, courts, and legal scholars (Rose, 1985:76).

In 17th-century southern Sweden, most hunting was limited to the nobility and resembled legislation in continental Europe, but in northern Sweden, including the Swedish lappmark, which encompassed two-thirds of the country, hunting was available to common people (Korpijakko-Labba, 1994; Nyrén, 2012). Availability did not mean the absence of institutions, only that rules were created in a local context with a bottom-up perspective. Hence, rules about hunting were created in a self-governing contextusers developed their own institutions for regulating, monitoring, and implementing resource use (Ostrom, 2005; Marklund, 2015:37; Larsson and Päiviö Sjaunja, 2020a). The first royal ordinance that regulated hunting in the Swedish lappmark was introduced in 1749 and was aimed at limiting settlers' hunting rights to one-half of a Swedish mile, or $5344 \mathrm{~m}$, from their homesteads. The ordinance reinforced that hunting rights across the Lappmark belonged to the Sami. The second ordinance, initiated in 1766, also targeted settlers and made it clear that it was strictly forbidden to hunt domestic reindeer (Stiernman, 1747-75).

Rules about hunting can be established at three levels (Ostrom, 2005:58). The first level is the day-to-day (operational) level where users have to make decisions about where to hunt, what gear to use, and who is going to participate. These decisions, in an early modern Sami context, are hard for us today to retrieve at the household level. The accounts we used as sources in this study provide some of this information. At the second (collective-choice) level, rules have to be established to determine who has the right to hunt where, or to regulate access. In early modern Sami society, these rules were likely made by small user groups or at the village level. Again, it is hard for us today to obtain information about the decision-making process. However, when users contested or violated these rules and the dispute could not be resolved within the user group, the matter could be taken to the local court, a trusted arena for solving conflicts. The court rulings from these proceedings were often preserved in writing, and they can tell us a lot about hunting. For example, they provide detailed evidence about which gear was used, which prey was hunted, and who participated in the hunt (Larsson, 2016; Larsson and Päiviö Sjaunja, 2020a). At the third (constitutional) level, rules are established regarding who has the right to participate in the collective-choice decisions, but discussion of constitutional rules is beyond the scope of this article.

Decisions about hunting, like decisions about other kinds of natural resource use, were impacted by the natural conditions, the attributes of the communities, and the rules in use (Ostrom, 2005). The SES framework was created for the analysis of closely coupled social-ecological systems and has been especially useful in analyzing the use of CPRs in a self-governance context (Cole et al., 2019). For us, the framework highlights that hunters (actors) in Lule lappmark were in positions to make choices among available options that affected outcomes such as social and ecological performance measures (McGinnis and Ostrom, 2014). We wanted to know how Sami decided who had the right to hunt and where, when, and what to hunt to achieve their goals.

\section{RESULTS}

The most noticeable physical divide, when it came to early modern hunting practices in Lule lappmark, was the ecological difference between the southeastern boreal forest and the northwestern Scandinavian Mountains, or Scandes. For early modern hunters, as for hunters today, ecology set the premise for hunting, foremost by determining which prey could be hunted and where. In our analyses of different aspects of early modern hunting in Lule lappmark, we used the division between boreal forest and mountains as a starting point.

Lule lappmark is located around $66^{\circ} \mathrm{N}$, literally on the Arctic Circle (Fig. 1). The climate is subarctic with long and typically very cold winters, and short summers with cool to mild temperatures. In the southeast, the landscape is dominated by boreal forest, known as taiga in Europe, Asia, and North America. It consists of a mix of Norway spruce (Picea abies), Scots pine (Pinus sylvestris), and downy birch (Betula pubescens), interwoven with innumerable bogs and lakes. The northwest has mountainous terrain. As in most of Scandinavia, the tree line is formed by Arctic downy birch (Betula pubescens var. tortuosa), and as the terrain rises, conifers become rare and montane birch forest takes over. In Lule lappmark, the tree line sits at an altitude of $600-700 \mathrm{~m}$. At higher altitudes, alpine tundra spreads out with a mix of montane grasslands, shrublands, rocky terrain, and glaciers. The highest mountain peaks rise just over $2000 \mathrm{~m}$.

\section{Hunting in the Mountains}

Hunters in northern Scandinavia have depended on reindeer (Rangifer tarandus) for food, clothing, and shelter since the end of the last ice age. There are traces of trapping systems in the mountains in Lule lappmark, which tell us that wild reindeer were hunted there (Manker, 1960; Mulk, 1994). According to Hollsten (1774:128), who resided in Jokkmokk parish, there were mountain reindeer, forest reindeer, and wild reindeer. He argued that the tame reindeer were mountain reindeer, which spent spring, summer, and autumn in the mountains and winters in the forest, and forest reindeer (skogs-renar), which stayed yearround in the forest. Wild reindeer resided in the lowlands 
east of the lappmark, toward the Gulf of Bothnia. No wild reindeer appeared to be in the southern part of Lule lappmark in the 1770s. However, in the northern part of the Swedish lappmark, including Kaitum in northern Lule lappmark, wild reindeer were present into the 19th century (Ekman, 1910).

In 1672, Tornæus (1900:55ff.) described the hunting of wild reindeer in the mountains of neighboring Torne lappmark (Fig. 1) during winter. In his description, hunters departed in pairs on hunting expeditions that could last for 8 to 10 weeks. They stalked herds of wild reindeer before crawling behind a rock or snowpack, close enough to shoot a designated animal using rifles. After having slaughtered the reindeer, the hunters placed the meat in a sled and continued to stalk the herd. Further evidence of wild reindeer in the mountains comes from a 1731 court case in Torne lappmark in which a user complained about repeated trespassing on his skatteland in the mountains by a user from another village (Arell, 1977:154).

On the organization of hunting, Tornæus (1900:55ff.) wrote that either antingen gar hela byn gemenligen (the whole village [went] together) or only a couple of villagers, and after the hunt, the prey was divided among the villagers. However, those who did not pay tax did not get a share, so it appears that reindeer hunting in the mountains took place on lands held in common by the tax-paying members of the Sami village. In the court case described by Arell (1977:154), the defendant had shot four reindeer of which two had been accrued to the proprietor of the skatteland. This case suggests that hunting of wild reindeer in the Torne lappmark mountains could be organized on private lands with the consent of the landholder.

Wild reindeer disappeared earlier in the Lule lappmark mountains than in the Torne lappmark mountains (Ekman, 1910). We did not find any evidence in the early modern accounts or in the court rulings of reindeer being hunted in the mountains of Lule lappmark.

Other animal species also were hunted in the mountains, namely Arctic fox (Vulpes lagopus L.), wolverine (Gulo gulo), and ptarmigan (Lagopus sp.). The Arctic fox is native to the alpine tundra and well adapted to life in a cold climate thanks to a dense, insulating, and multilayered pelage that changes colour seasonally between light grey in summer and white in winter, or stays dark blue, brown, or grey year-round. When Rheen (1897:58) listed Sami trade articles in 1671, he included pelts from black and red foxes (both Vulpes vulpes) as well as skins from blue and white foxes (both $V$. lagopus). According to Rheen (1897:54), who mostly described Lule lappmark, Arctic foxes were found only in the mountains. He moreover described that fox hunting was more difficult in years when there was an influx of Norway lemmings (Lemmus lemmus L.). In such years, the foxes feasted on lemmings and did not as willingly seek out carrion that hunters deployed, which suggests that traps were a common method for catching foxes. The method seems rational, as furs certainly must have been priced higher if they were unmarked by bullets, and as foxes, according to Linnaeus (2003:58), were not hunted for human consumption. We have found only one court ruling from Lule lappmark that concerns hunting in the mountains (HRA, 1704:804). The particular case involved two brothers in Sirkas who disputed who had the right to the furs from two foxes and one wolverine. The defendant argued that he alone had caught the animals, while the plaintiff claimed they had hunted $i$ samma wanher (in the same traps). Since they had shared the traps, the plaintiff claimed that they both should have a right to the prey. The court proceeding ended by the brothers agreeing to sell the coats and split the earnings between them.

Another prey animal was the gamebird ptarmigan. The Rock Ptarmigan (Lagopus muta) was native to the mountains but not the forests. The Willow Ptarmigan ( $L$. lagopus L.) resided in both lower mountain terrain and boreal forest. For early modern hunters, their feathers and meat were attractive returns. Linnaeus (2003:106-107) described how all households engaged in reindeer herding in Lule lappmark moved to the boreal forest in winter, and that only some of the poorest inhabitants stayed in the mountains to snare ptarmigans. He described that hunters could snare up to 40 or 50 birds during one night. Högström (1747:97) likewise wrote that poor Sami in Lule lappmark sometimes stayed in the mountains during winter, surviving on abundant catches of ptarmigan. Even so, he stated that hunters had to combine the ptarmigan diet with other meat since bird meat allegedly was not nutritious enough to survive on. Niurenius (around 1640) (1905:19), Rheen (1897:53), and Tornæus (1900:60) also described the snaring of ptarmigan in winter. Both Linnaeus (2003:101, 138) and Högström (1747:86) described that inhabitants who lived in the mountains in summer were not especially engaged in hunting and not particularly accomplished hunters; few of the households they visited in the mountains owned rifles or steel bows (crossbows). According to them, reindeer herders' hunting efforts were directed toward either squirrel with wooden bows in the forest in winter, or ptarmigans with snares. Holm described that in the mountains of Ume lappmark there were few bird species to eat other than ptarmigan (Norstedt, 2011:105, 108).

\section{Hunting in the Boreal Forest}

Many more species of prey animals were native to the boreal forest than to the alpine tundra, and early modern sources mentioned several in accounts and court cases regarding forest hunting. Furthermore, forest inhabitants were generally portrayed as proficient hunters, skilled in both making traps and shooting. Högström (1747:85) described hunting as fundamental for all households in the forest of Lule lappmark. Linnaeus (2003:138) similarly described the inhabitants as skilled marksmen. Several animal species were mentioned in lists of traded goods in the lappmark: otter (Lutra lutra), wolverine, lynx (Lynx lynx), marten (Martes martes), fox (red and black), beaver (Castor fiber), grey or red squirrel (Sciurus vulgaris), wolf 
(Canis lupus), and bear (Ursus arctos arctos) (Rheen, 1897:58; Tornæus, 1900:63).

The sources told us that wild reindeer were present in the boreal forest of Lule lappmark in the 17th century (Rheen, 1897:23). Wild reindeer there were hunted with snares, spears, rifles, or bows and arrows (Rheen, 1897:23). The use of bows, snares, and spears was also corroborated by two court rulings from Lule lappmark (HRA, 1699:76-85; RA SH, 1741:784). In 1672, Graan (1899:42) described how 17th-century hunters in Ume lappmark got plenty of food from wild game, such as wild reindeer, which, according to him, were hunted in the forest, rarely in the mountains. The hunt for wild reindeer was described as year-round, especially around St. Matthews Day in September, which was the rutting season, in early spring when the snow cover was deep, and in summer. In autumn, hunters stalked herds of wild reindeer in the forest using a tame vaja (female reindeer) to attract bulls, which would then be killed with rifles or bows. The winter hunt was performed on skis; while the hunters stayed on top of the snow, a reindeer sank into the snow, which made it relatively easy to catch up and kill it. Hunters had the most luck in snow-rich winters as a thick snow cover favored hunting of most forest animals (Lundius, 1905:26). Lundius (1905) mentioned how a hunter in one single day had felled 16 wild reindeer. Inhabitants in Ume lappmark were also said to have stalked wild reindeer in the forest in summer, equipped with rifles or bows (Niurenius, 1905:17). However, Holm described how hunting wild reindeer in the summer was not customary since meat and skins were destroyed by insects (Norstedt, 2011:84). Further, Holm's account describes how some skatteland had many wild reindeer and some had few (Norstedt, 2011:65, 73).

Aside from hunting with rifles or bows, 17th-century sources from Ume lappmark described how inhabitants there used trapping pits to catch wild reindeer (Lundius, 1905:22; Niurenius, 1905:17). The pits were set up in narrow gorges, delimited by steep cliffs or other impassable terrain, where the wild reindeer usually passed in winter. In the midst of the gorge, several deep pits were dug and covered with fine twigs and mosses. On top, loose snow was shuffled to hide irregularities. The hunters either waited the reindeer's voluntary passage, or actively startled them so they moved toward the pits.

After Linnaeus (2003:44) had traveled in Ume lappmark in 1732, he stated that "willrenar finnas sällan $i$ Lapmarken, förnämligast finnas någre på Almänningen emällan Granöen och Lyksele" [wild reindeer are seldom found in the lappmark, mostly they reside on a common land between Granön and Lycksele], located at the eastern border. He also wrote that reindeer herders sometimes lost tame reindeer to wild herds but that they usually got them back the following year. The tame reindeer would then be herded back to the flock by its owner or, if it did not comply, it would be shot. If reindeer traps were used, they could have easily become a hazard for tame reindeer and cause problems for reindeer herders (Arell, 1977:99-101). The last evidence that we found about wild reindeer hunting in Lule lappmark came from a court case in 1741 (RA SH, 1741:784). The court decided that a settler who had deployed a wild reindeer trap in the eastern part of Sjokksjokk had to reimburse the owners whose reindeer got caught in his trap.

The distribution of elk (Alces alces) is hard to interpret. According to Lundius (1905:12, 40), there were normally no elk in Lule lappmark, but Ume lappmark had both elk and wild reindeer in abundance. However, in Holm's detailed descriptions of game in each skatteland, elk are not mentioned in Ume lappmark (Norstedt, 2011:39). Holm's task was to assess the value of resources of each skatteland. Since he does not mention elk, he cannot have seen it as a reliable asset for the landholder. The elk must have been absent or at least very rare. In Torne lappmark, Torneaus (1900:55) described that elk had existed in past times.

The wolverine is native to both the Arctic tundra and the boreal forest. In a text about wolverines in Lule lappmark, Hollsten (1773:232) stated that the animal resided in forests near a mountain with rugged terrain to which they could flee when they were hunted. Wolverines have dark-colored, dense, water-repellant greasy fur. Their coats appear in early modern trade lists from Lule lappmark, which suggests they were hunted there (Lundmark, 1982:198-203). According to Holm in 1671, wolverines were common in Ume lappmark but hard to catch and were hunted to prevent them from breaking into storage places, such as buildings and mountain crevasses (Norstedt, 2011:72). Hollsten (1773:235) described them as a great nuisance because they ate the food that people had stocked to use during their return to the mountains in spring. Hunting methods included trapping with steeljawed leghold restraint traps that were heftier than ordinary traps and hunting on skis with a spear for the final killing. Lundius (1905:28) corroborated trapping wolverines in his account from ca. 1674 of practices in the boreal forest in Ume lappmark.

Sami considered bears to be the most prominent creatures in the forest because of their superior strength compared to other animals (Rheen, 1897:43). This belief probably contributed to numerous rituals that surrounded bear hunts and the subsequent preparation and disposal of meat and bones, described by several authors (Högström, 1747:209; Rheen, 1897:43ff.; Niurenius, 1905:18). Linnaeus (2003:148) described bear hunting as stalking by a single man with a dog; once a bear was found, the hunter crawled close enough to shoot it. The hunts took place in autumn when bears were busy eating berries. Rheen (1897:43ff.) described a more collectively organized hunt in Lule lappmark, where a person who had found a hibernating bear's den gathered family and friends to help wake and kill it. Killings were performed with either spears or rifles. The bear hide was reserved for the person who had located the den, and the meat was divided among all participants in the hunt. Niurenius (1905:18) specified the time period for bear hunting in Ume lappmark as March and April, when the bear was still in its den but right before it normally awoke. 
The priest Pehr Fjellström ([1755] 1981:9) wrote about the rituals surrounding bear hunting and described a common law among inhabitants wherein the proprietor of a skatteland where a bear had been killed got a share of the meat, regardless of whether or not he or she had participated in the hunt. If the proprietor had participated, he or she got to choose the first share and then received the share due to each participant.

Several court rulings from Lule lappmark dealt with bear hunting and gave a different picture. In one case from 1709, two bear hunters from Jokkmokk were the plaintiffs (HRA, 1709:343). They claimed to have woken a hibernating bear and thereafter encircled it on their own skatteland. However, before they could kill the bear, it had run off to a neighboring property where it eventually had been killed by the defendants. In court, the plaintiffs demanded a share of the bear's fur from the defendants, but since the court was not convinced that it was the same bear, the verdict went in favor of the defendants, and the plaintiffs were left empty-handed.

A parallel case was brought to the court just a few days later. In that case, two men in Sjokksjokk had encircled a bear on another user's skatteland and then shot it (HRA, 1709:357). Thanks to the effort of the men at the beginning of the hunt, the court decided they had rights to one-third of the value of the bear's coat. Even if it was not made explicit in the verdict, it seems reasonable that the remaining twothirds accrued to the landholder.

In 1742 and 1744, two more court cases dealt with bear hunting. The first involved a dispute between a user in Jokkmokk and a user in Sjokksjokk (RA SH, 1742:254). The second case involved a user from Jokkmokk and a user from Sirkas (RA SH, 1744:289). In both cases, the verdicts had been postponed: in the first case, the court needed to find out who owned the land where the bear had been killed; in the latter case, the defendant never appeared in court. Neither of these cases seems to have been reopened, probably because the parties reached settlements outside court.

The court rulings show that the meat and coat from a killed bear belonged to the holder of the skatteland where it had been shot (Korpijaakko-Labba, 1994:260-261; Korhonen, 2007). Yet, it was possible to get a share if a person had participated in the bear hunt before the bear fell, even though it was not on his or her land. In court rulings that explicitly mentioned the number of hunters, they always hunted in pairs. This also goes for a case from 1707 where a father and son from Sjokksjokk stood accused of reindeer theft (HRA, 1707:145-149). In defense, they argued they could not have stolen any reindeer since they were out hunting bear at the time.

Between 1572 and 1615, 77 beavers from Lule lappmark were sold or paid in tax to the Swedish crown (Lundmark, 1982:191-203). However, according to an account from the 17th century, there were beavers in Ume but not in Lule lappmark (Lundius, 1905:12). Beavers were favored prey for their valuable castoreum. Fjellström (1760:21) wrote that castoreum was so expensive in the pharmacies in Sweden that Sami should have sold it to Swedish merchants instead of taking it to markets in Norway. Because the beaver skins were already being sold to Swedish merchants, they should have been able to offer as much for the castoreum as the Norwegians did.

The source materials reveal little to no information about hunting of many species of small game. Squirrel hunting was especially important for many households in the lappmark, and we know that Sami in Lule lappmark paid taxes in squirrel pelts, which represented the bulk of traded furs (Lundmark, 1982). Linnaeus (2003:61) described squirrel traps made of logs that had been split in two. In an account from the mountains, he previously had described how efficiently Sami handled wooden bows when they hunted squirrels in the forest. In Holm's account, squirrels and other small game are listed for almost all skatteland in Ume Lappmark (Norstedt, 2011:39). For some land in the boreal forest, squirrels are listed as rather abundant (Norstedt, 2011:89, 114). In the court records from Lule lappmark, we found two cases concerning squirrels (HRA, 1711:759-760; RA SH, 1757:496-497). Both are from Sjokksjokk and point out that squirrels belong to the holder of the land. Coats from martens are mentioned in early modern trade lists, and Niurenius (1905:19) described that martens could be killed with arrows while they were up in trees, but that the most common hunting method was to use fire to smoke them out of their hiding places in mountain caves and crevasses. They were then caught in nets tied in front of the entrance.

Forest inhabitants also engaged in hunting fowl for meat, feathers, and eggs. The feathers were used in the household and for trade, while the meat and eggs mostly were consumed within the household. Other materials from the birds also were used, such as skins for watertight containers.

Rheen (1897:53) listed land fowl that resided in the boreal forest in Lule lappmark, such as Western Capercaillie (Tetrao urogallus L.), Black Grouse (Lyrurus tetrix L.), and Hazel Grouse (Tetrastes bonasia L.). Both Tornæus (1900:60) and Rheen (1897:53) listed several species of waterfowl that were present in northern Scandinavia during summer, such as Whooper Swan (Cygnus cygnus) and various species of geese and mallards, such as Common Goldeneye (Bucephala clangula L.), Swartor (probably Velvet Scoter [Melanitta fusca]), Black-throated Diver (Gavia arctica), Red-throated Diver (Gavia stellata), and Goosanders (Mergus merganser). Several methods were used in bird hunting. Linnaeus (2003:62) wrote that he had seen traps for capercaillie along paths all over Ume lappmark and that these traps were deployed in autumn. At least in Ume lappmark, traps were also used to catch waterfowl, such as geese and swans (Lundius, 1905:17). Moreover, both Ehrenmalm (1743:128) and Lundius (1905:18) described that inhabitants hunted forest fowl with rifles. Ehrenmalm specified that forest Sami shot plenty of birds in spring. Linnaeus (2003:118) described 
how he nearly had been hit by a misdirected bullet fired by a bird hunter when he was out picking wild strawberries (Fragaria vesca) in the mountain valleys of northern Norway, just across the border from Lule lappmark. Sources also mentioned that waterfowl were caught in nets but did not specify if hunters were trying to catch birds or if it happened as a bycatch in fishing nets (Tornæus, 1900:60).

We have not found any particular bird species mentioned in court rulings from Lule lappmark. However, bird hunting in general can be affirmed, for example, in a case where plaintiffs and defendants used bird traps (RA SH, 1777:45-46). Bird hunting was also stated in several disputes over rights to use specific skatteland, where the court saw long-term use of bird traps as a valid argument for the bird hunter to obtain continuous user rights (RA $\mathrm{SH}, 1772: 485)$. All cases regarding bird trapping in Lule lappmark that we found had unfolded in the boreal forest. We learned that users in the mountains snared ptarmigan and probably trapped other birds, although it is not noticeable in the court records. The lack of court cases regarding bird hunting in the mountains is probably because there were fewer bird species there than in the forest, thus less hunting. Also, and maybe more important, because the institution of skatteland was more widespread in the forest, which provided the opportunity for more disputes over rights (Hultblad, 1968). Court records from Lule lappmark by and large described the trapping of birds, whereas only one court ruling mentioned fågelskjutande (bird shooting) (HRA, 1709:352).

Aside from bird hunting for meat and feathers, Sami also gathered bird eggs. There were specially built nesting places for gathering eggs (Tornæus, 1900:60; Lundius, 1905:16). These birdhouses were made of hollow trunks with a man-made hole in the middle and ends plugged with moss. The birdhouses were attached to trees and were emptied as soon as the birds laid their eggs in them. Hunters also collected swan eggs on mires and tufts after the birds had been snared.

The only evidence we found that revealed anything about the extent of hunting in Lule lappmark came from a court case in 1737. The defendant, a man from Sjokksjokk, was charged for unlawfully using a skatteland. The right to the land had originally belonged to the father of the current user, who had given the defendant provisional rights to hunt there, but only until his son, the plaintiff, had come of age to use it. The court decided that the defendant no longer could use the land and thus approved the plaintiff's demand. As a consequence, the defendant wanted to be compensated for traps he had deployed on the land. This request was approved by the court, and he was compensated for a total of two hundred traps, divided equally between flakar (log traps) and giller (cage traps). The traps were described as well functioning and therefore worth a total of 12 daler copper coins (RA SH, 1737:682). It was obviously problematic to remove the traps, and therefore reasonable for the plaintiff to reimburse the defendant for their worth. Although this evidence concerns one specific case, it suggests that one land parcel could contain hundreds of traps. Besides the 200 traps, the defendant might have had other, less complicated traps made of wires and ropes that easily could have been removed; he also might have hunted small game with bow and rifle.

Small-game hunting seems to have been a particularly important income source for the poor. This was highlighted in a court ruling from 1701 where the plaintiff, a man from Jokkmokk, accused two sisters of having destroyed a couple of faggelflakar (log traps for birds) and the floor of an akkja (sledge) that belonged to him. According to the sisters, it was instead the plaintiff who had acted unlawfully, both by destroying several of their bird traps and by striking them with rods and twigs. All in all, the court argued that the sisters' offense was minor and that the plaintiff had a greater liability. The court's main argument was that the plaintiff had acted unjustly toward two simpleminded women, and that he should have been able to handle the situation differently. Moreover, the court stated that since the two sisters lived in great poverty, the plaintiff should compensate them with six daler (copper coins) or a vajren (female reindeer). The women also had the right to continue using bird traps on his land. The court emphasized that the plaintiff should icke förtaga dem deras närings och lifsupphälle (not take away their livelihood and life support) and that the sisters, for their part, had to show respect and good manners toward the plaintiff (HRA, 1701:406-408). From Pite lappmark, Öhrling ([1773] 1970:11) wrote that those who were very poor sought their livelihoods solely from hunting and fishing.

\section{DISCUSSION}

\section{Mountain and Forest}

With regard to ecological settings, the most important natural conditions that impacted decisions regarding hunting in Lule lappmark between 1660 and 1780 were the differences between mountains and forest. While the forest had many species of mammals and birds, the mountains did not. The same observation was made by Holm in his account of Ume lappmark in the 1670s (Norstedt, 2011:105, 107). The compositions of prey species in the two regions were stable during the study period, but some important changes that had started in the late 16th century impacted hunting strategies and outcome.

The 16th century saw an increased demand for expensive furs and a trade that flourished until it peaked in the 1570s (Hansen and Olsen, 2014:237-239). Fur trade declined rapidly in Lule lappmark in the beginning of the 17th century (Lundmark, 1982:120). Lundmark (1982) suggested that the decline was caused by an overharvest of fur animals, but another possible explanation was the emergence of new trade patterns that increased the fur import to Europe, first from Russia and later from North America (Brook, 2008). However, it is likely that the slow, 
long-term decrease occurred for three reasons: (1) Furs continued to be sought-after goods in local trade even after they lost importance in international trade. Hunters could easily see how income from the fur trade would improve the household economy, especially in the forest where fur animals were abundant at the time. (2) The increase in the human population in the 18th century led to increased hunting pressure. (3) Some wild animals were a nuisance to people-stealing their stocked food or attacking their domestic reindeer - and had to be killed.

The developments surrounding wild reindeer are more lucid than for fur animals. It is difficult to pursue reindeer herding in areas with wild reindeer. Vorren $(1978,1980)$ established a temporal correlation between the decline of wild reindeer and the emergence of reindeer nomadism in the Finnmark region of northern Norway during the first half of the 18th century. Lundmark (1982:162-163) argued that a similar development occurred in Lule lappmark and that the extinction of wild reindeer was intentional. It began in the mountains and ended in the easternmost forest of Sjokksjokk, where wild reindeer were rare by the mid-18th century. We know relatively little about how wild reindeer were distributed in the mountains in early modern Lule lappmark. In fact, wild reindeer were mentioned in only one source from 1608 (Lundmark, 1982:163), and their presence was indirectly confirmed by the remains of pitfall systems (Mulk, 2005:48). When Sami with access to mountain grazing developed large-scale reindeer nomadism, wild reindeer would have had no place in the mountains, which explains their rapidly decreasing numbers. According to Holm, there were no wild reindeer in the mountains of Ume lappmark in 1671, although they were abundant in some of the skatteland in the forest (Norstedt, 2011:38). Pitfalls thus became useless and hazardous for domestic reindeer. From the mid-17th century at the latest, wild reindeer must have been extinct or at least very rare in the mountains.

Some court rulings from the first decades of the 18th century contain information about wild reindeer being present in the forest in Lule lappmark. The last one was dated in 1741 and mentioned a trap for hunting wild reindeer. According to Hollsten (1774), wild reindeer were rare in Lule lappmark but remained in the forests between Lule lappmark and the farming districts in the east. In Sjokksjokk, in the eastern part of Lule lappmark, the disappearance of forest reindeer coincided with the introduction of large-scale reindeer nomadism around 1750 (Hultblad, 1968).

Small-game hunting for international trade lost importance in the 17th century; however, small-game hunting for subsistence was still important. It reinforced the forest as the primary arena for hunting. The forest offered an abundance of animals, while the mountains offered relatively few. Hence, households in the forest had more opportunities to hunt.

\section{The Purpose of the Hunts}

The source materials give an insight into the major reasons behind why households in Lule lappmark hunted in the 17th and 18th centuries. First, people needed fat and protein from wild animals for consumption. Second, Sami needed products for trade and paying taxes, for example, skins from a wide range of animals, such as squirrels, foxes, bears, and martens, and feathers from wild fowl. Third, hunters wanted to prevent predators, particularly wolverines, bears, and wolves from damaging their stored food and tame reindeer (Högström, 1747:85; Linnaeus, 2003:138). Besides these three practical and functional motives for hunting, there was surely a fourth, intangible motive: the feelings of excitement, joy, and reward that continue to entice modern-day hunters.

\section{Property Rights}

Two central questions in this study focused on who had the right to hunt and where they could hunt. The answers for forest hunting were connected to proprietorship of skatteland, meaning that rules for access were well defined among users. In the mountains, on the other hand, distribution of skatteland was less clear, and users often had open access to hunting.

In the forest, users were more dependent economically on hunting, and having as much control as possible over the resources was key. Much of the previous research on Sami land rights centered on the institution of skatteland (Korpijaakko-Labba, 1994; Lundmark, 2006; Norstedt et al., 2014), a term known since the mid-17th century as the amount of land for which a Sami paid tax. In the forest, there was strict division on which individual households had private rights to grazing land, fishing waters, and hunting grounds. The boundaries between properties were usually well known; if not, the local court helped to set the borders. As soon as a wild animal dwelled on a skatteland, it was seen as the property of the proprietor of that land. Ownership of the animal shifted when it strayed to another person's land. In Lule lappmark, all but one of the hunting disputes taken to court took place in the boreal forest. Hultblad (1968:118) showed that most of the forest in Sirkas, Tuorpon, Sjokksjokk, and Jokkmokk was divided into skatteland. Arell (1977) conveyed that most court cases regarding hunting in Torne lappmark dealt with uncertainties over boundaries in relation to the disputed natural resources.

The formation of hunting rights in the forest followed many of Ostrom's (1990:90) design principles for sustainable use of CPRs. Well-defined user groups and resource areas made it possible to control the amount of resources withdrawn from each skatteland, which in turn reduced the risk of overuse. If the use of a resource was contested or if trespassing occurred, the local court functioned as a collective-choice arena that mediated between users, clarified boundaries between lands, and penalized someone 
who violated the rules (Larsson and Päiviö Sjaunja, 2020b). Clear boundaries between users' lands made it easier to monitor regulations, even though very large skatteland still might have been difficult to control fully.

Small-game hunting favored lands that were used individually for two reasons. First, hunting small game often entailed using traps, which in turn became investments in the land; for example, fixed log traps took time to construct and were difficult to move. A household could have had several hundred such trapping devices on its skatteland. Second, small-game hunting required users to have great knowledge about the whereabouts and behavior of prey animals in order to deploy the right trap in the right place. The traps also had to be monitored regularly, which required hunters to deploy them near their living grounds. Many aspects of hunting were thus facilitated if users had detailed knowledge about and easy access to land. If a skatteland was used by more than one household, each household had its own traps, and the prey animals accrued to the household that had deployed them. Trapping is for the most part an extensive hunting method, and many traps are required for it to be rewarding. The probability of catching a prey animal increases if the hunter has large numbers of traps deployed in as many strategic places as possible.

Large prey animals in the forest also accrued to the proprietor of the skatteland where they were felled, but this rule could be set aside by mutual agreements between involved parties. If someone had been instrumental in the pursuit of a bear prior to the killing, it was possible for him or her to get a share even without belonging to the household of the landholder. Opposite to the rest of Sweden, where pest animals could be killed and claimed by anyone, in the lappmark they belonged to the landholder (Korpijaakko-Labba, 1994:263).

There were no such strict regulations regarding access to hunting or to whom a felled wild animal belonged in the Lule lappmark mountains. However, where wild reindeer were present in Torne lappmark during the 17th century, the hunt was regulated by the villages. Since there were fewer species of wild animals in the mountains than in the forest, hunting played a less important role in the household economy. Early modern sources were vague when it came to the organization of hunting in the mountains, but there was no clear evidence of its being tied to skatteland, and it seemed as if users were allowed to hunt freely.

A tax account from 1695 stated that 18 out of 43 users in Sirkas and no users in Tuorpon had skatteland (Holmbäck, 1922). During the preparatory work for the demarcation of the Swedish-Norwegian border in 1745, an account of the activity stated that engineers had been told there was no strict division between these two villages and that the land was used efter behag (as they pleased) (Wiklund and Qvigstad, 1909:17-18). Holmbäck (1922) concluded that the early modern division of land in the mountains could not have been very strict. This conclusion is also confirmed by court rulings in the mountains, where grazing lands were used alternately by villagers from Sirkas and Tuorpon
(Hultblad, 1968:368 evidence no. 213a, 370 evidence no. 270a). Users in the mountains apparently had open access to hunting, although it was comparatively low yielding.

Hunting was often described as a collective enterprise organized and regulated by the Sami village and where the wild animals were a CPR (Ingold, 1980; Mulk, 1994; Bergman and Ramqvist, 2018). However, 17th- and 18th-century sources told us that hunting in the forest was organized individually or at the household level, and that wild animals belonged to the holder of a skatteland where they appeared. Hunting in the mountains, after the disappearance of wild reindeer, was also organized individually, albeit wild animals were most likely seen as a CPR.

Earlier research assumed that skatteland represented an older organization, predating their first appearance in the sources from the 17th century (Holmbäck, 1922). Other scholars did not perceive them as originally Sami, but rather as the result of the Swedish government's desire to organize taxation by connecting all inhabitants to specific lands (Hansen and Olsen, 2014). The origin of skatteland is complex; however, the organization of land into welldefined user parcels makes sense when we consider the organization of fishing and hunting in the forest from the mid-17th century to the second half of the 18th century. Norstedt (2018:65) argues that skatteland were created "to achieve a satisfactory division of predictable and dense resources" and points to fishing as the determinant factor. Well-defined properties made it possible for landholders who relied on fishing and hunting to gain control over resources that were fundamental for their survival. The idea of hunting as a collective enterprise or of wild animals as a CPR does not fit with the way land was actually organized in the early modern period. Hence, we suggest that the organization into skatteland was a response to changes in the Sami economy, and that changes in the organization of hunting, from collective to private, was one of the contributing factors in that development.

\section{Who Participated in Hunting?}

Before 1600, hunting in the lappmark was described, albeit from sketchy evidence, as a task performed mostly by men. Men left home to hunt wild reindeer or bears and returned with the prey to share it within a group of neighbors and relatives. It is probably an exceedingly onedimensional description of medieval and prehistoric hunting (Mulk, 1994), but due to the sources, and the dominating portrayals of hunting therein, little else is known about who actually hunted historically. The shift from portraying hunters as main characters to not describing them at all coincided with the expiration of wild reindeer hunting and the increased importance of large-scale reindeer nomadism, which led to the portrayal of Sami after the 16th century as reindeer herders.

The fundamental change in hunting in the early modern period, from producing a surplus of furs for trade to a 
subsistence mode, might have changed who participated. In the early modern accounts, young boys, for example, were said to have practiced squirrel hunting with bows from an early age. And it is fair to conclude that the authors' own views of gender division of labour from childhood to adulthood relatively uncritically transferred into their descriptions of Sami customs. Men moved around, chasing and hunting large animals, and women were mostly invisible or stayed at home. An example would be accounts that present a vivid picture of men being part of ritual bear hunting (Tornæus, 1900:59-60; Niurenius, 1905:14), although Kuhmunen (2015) has shown that women participated in the rituals when the bear was brought home. The use of weapons - rifles, bows, and spears - was associated with men.

Accounts and court rulings gave plenty of evidence of small-game hunting that took place close to the living grounds, and it seems obvious that both men and women participated. Common tasks were to build, place, and monitor the traps to catch small game. Since one household could have had several hundreds of traps, it would have been a time-consuming endeavour and thus a shared responsibility for several household members. For most species of small game, there was also seasonal variation in the number of prey animals; during the high season, all the available work force in the household must have been needed, regardless of gender or age. Catching waterfowl must have required the same workforce whenever households had to optimize harvests of meat, eggs, and feathers during the few summer months before the birds migrated. Moreover, many of the work tasks related to fishing and reindeer husbandry were performed by both men and women (Larsson and Päiviö Sjaunja, 2020b), as was true also for many of the household chores, such as food preparation and cooking. There was thus a tradition of sharing labor. Small-game hunting became the major hunting activity and was more predictable than large-game hunting. Hence it contributed to subsistence, and women's roles in hunting would have increased. Hunting was not gender neutral, but women's and children's roles in early modern small-game hunting have largely been invisible.

\section{Social Justice}

Small-game hunting for subsistence played an important part in upholding social justice among the Sami. Poor people could, for example, stay in the mountains in Lule lappmark in winter to hunt ptarmigan, where users had open access to hunting. Despite this, there was probably little risk of overharvest since there were few hunters on relatively vast lands. Hunting by poor people was not limited to the mountains; they also could hunt small game on skatteland in the forest. If landholders claimed that these people's hunting was an intrusion, the court could decide that they had rights to continue hunting because they were underprivileged (HRA, 1701:406-408).
Small-game hunting likely increased in importance in the early modern period, even though the scarcity of information from previous centuries makes it impossible to prove. Small-game hunting was likely motivated by a growing population that made people search for alternative incomes, especially Sami who did not participate in largescale reindeer herding, which included many households in the boreal forest, particularly poor households in both forest and mountains. The larger picture implies that the gap between wealthy and poor inhabitants in Lule lappmark increased during the early modern period due to population growth and the expansion of large-scale reindeer herding, which yielded great surpluses for herders (Kvist, 1989). Hunting was one way to alleviate poverty for those who remained on the wrong side of the gap, and to prompt social equity, the rights of the poor to hunt were often confirmed by the community via the local court.

\section{CONCLUSION}

In our overview of early modern hunting with a focus on Lule lappmark, we show how hunting was performed and how it changed during the study period. By using a selfgovernance perspective, we highlight Indigenous users' abilities to build institutions, rules, and norms for natural resource management with respect to hunting. Hence, we advance the understanding of early modern hunting in northwestern interior Fennoscandia.

\section{ACKNOWLEDGEMENTS}

Funding by the Royal Swedish Academy of Letters, History and Antiquities and the Swedish Research Council (2018-01571) is gratefully acknowledged. Thanks also to freelance editor Joanna Broderick and the anonymous peer reviewers of Arctic.

\section{REFERENCES}

Arell, N. 1977. Rennomadismen i Torne lappmark [Reindeer nomadism in Torne Lappmark]. Dissertation, Umeå University, Umeå, Sweden.

Bergman, I., and Ramqvist, P.H. 2018. Hunters of forests and waters: Late Iron Age and Medieval subsistence and social processes in coastal northern Sweden. Acta Borealia 35(1): $1-28$.

https://doi.org/10.1080/08003831.2018.1456765

Bergman, I., Zachrisson, O., and Liedgren, L. 2013. From hunting to herding: Land use, ecosystem processes, and social transformation among Sami AD 800-1500. Arctic Anthropology 50(2):25-39.

https://doi.org/10.3368/aa.50.2.25

Bjørklund, I. 2013. Domestication, reindeer husbandry and the development of Sámi pastoralism. Acta Borealia 30(2):174-189. https://doi.org/10.1080/08003831.2013.847676 
Brook, T. 2008. Vermeer's hat: The seventeenth century and the dawn of the global world. New York: Bloomsbury Press.

Cole, D.H., Epstein, G., and McGinnis, M.D. 2019. The utility of combining the IAD and SES frameworks. International Journal of the Commons 13(1):244-275.

https://doi.org/10.18352/ijc.864

Ehrenmalm, A. 1743. Resa igenom Wäster-Norrland till Åsehle lappmark [Journey through Wäster-Norrland to Åsele lappmark district]. Stockholm: Kungliga boktryckeriet.

Ekman, S. 1910. Norrlands jakt och fiske [Hunting and fishing in Norrland]. Uppsala: Almqvist \& Wiksell.

Fjellström, C.P. 1760. Tankar om upodlings möjelighet i Lappmarkerne [Thoughts about the possibility of cultivation in the Lappmark]. Dissertation, Uppsala universitet, Uppsala, Sweden.

http://uu.diva-portal.org/smash/get/diva2:1173960/ FULLTEXT01.pdf

Fjellström, P. (Pehr). [1755] 1981. Kort berättelse om lapparnas björna-fänge, samt deras der wid brukade widskeppelser [Short story about the Sami bear-hunt, as well as related superstitions]. Facs.-utg. Umeå: Två förläggare.

Fjellström, P. (Phebe). 1962. Lapskt silver [Sami silver]. Stockholm: Almqvist \& Wiksell.

- 1986. Samernas samhälle i tradition och nutid [Sami society in tradition and the present day], 2nd ed. Stockholm: Norstedt.

Graan, O.S. 1899. Relation, eller en fulkomblig beskrifning om lapparnas ursprung, så wähl som om heela dheras lefwernes förehållande [Relation, or a complete description of the origin of the Sami, as well as their entire living conditions]. Uppsala: Harald Wretmans tryckeri.

Hansen, L.I. 1990. Samisk fangstsamfunn og norsk høvdingeøkonomi [Sami hunting society and Norwegian chief economy]. Oslo: Novus.

Hansen, L.I., and Olsen, B. 2014. Hunters in transition: An outline of early Samì history. Leiden: Brill.

Henriksson, H. 1978. Popular hunting and trapping in Norrland. Stockholm: Kungl. Vitterhets Historie och Antikvitets Akademien.

Högström, P. 1747. Beskrifning öfwer de til Sweriges krona lydande lapmarker [Description of Sami districts belonging to the Swedish crown]. Stockholm: Salvius.

http://urn.kb.se/resolve?urn=urn:nbn:se:umu:eod-114

Hollsten, J. 1773. Anmärkningar om järfven [Remarks on the wolverine]. Stockholm: Vetenskaps Akademiens handlingar.

- 1774. Afhandling om renen [Dissertation on the reindeer]. Stockholm: Vetenskaps Akademiens handlingar.

Holmbäck, Å. 1922. Om lappskattelandsinstitutet och dess historiska utveckling [On the institution of taxation lands and its historical development]. Stockholm: Statens offentliga utredningar.

HRA (Härnösand Regional Archive). 1689-1715. Rulings in Västerbotten District Court, Sweden. Härnösand: Swedish National Archives.
Hultblad, F. 1968. Övergång från nomadism till agrar bosättning i Jokkmokks socken [Transition from nomadism to farming in the parish of Jokkmokk]. Dissertation, Uppsala University, Uppsala, Sweden.

Hvarfner, H., ed. 1965. Hunting and fishing. Nordic Symposium on Life in a Traditional Hunting and Fishing Milieu in Prehistoric Times and Up to the Present Day, 28 May-1 June 1962, Luleå, Sweden. Luleå: Norbottens Museum.

Ingold, T. 1980. Hunters, pastoralists and ranchers: Reindeer economies and their transformations. Cambridge: Cambridge University Press.

Jansson, U., ed. 2011. Agriculture and forestry in Sweden since 1900. Stockholm: Norstedts Förlag.

Josefsson, T., Bergman, I., and Östlund, L. 2010. Quantifying Sami settlement and movement patterns in northern Sweden 1700-1900. Arctic 63(2):141 - 154 . https://doi.org/10.14430/arctic970

Kjellström, R. 2000. Samernas liv [Sami living]. Stockholm: Carlssons förlag.

Korhonen, O. 2007. Jägaren och björnceremonierna [The hunter and the bear ceremony]. Svenska Landsmål och Svenskt Folkliv 333:27-49.

Korpijaakko-Labba, K. 1994. Om samernas rättsliga ställning i Sverige-Finland [On the legal position of the Sami in SwedenFinland]. Helsinki: Juristförbundets förlag.

Kuhmunen, A.W. 2015. A female perspective on bear hunting. Journal of Northern Studies 9(2):73-94.

Kvist, R. 1989. Rennomadismens dilemma, det rennomadiska samhällets förändring i Tuorpon och Sirkas, 1760-1860 [The dilemma of nomadic reindeer pastoralism. The changing reindeer pastoralist society of Tuorpon and Sirkas, 1760-1860]. Disseration, Umeå University, Umeå, Sweden.

Larsson, J. 2016. Conflict-resolution mechanisms maintaining an agricultural system. Early modern local courts as an arena for solving collective-action problems within Scandinavian civil law. International Journal of the Commons 10(2):1100-1118. https://doi.org/10.18352/ijc.666

Larsson, J., and Päiviö Sjaunja, E.-L. 2020a. Early modern reindeer husbandry, Sami economy, and grazing rights. International Journal of the Commons 14(1):91-107.

https://doi.org/10.5334/ijc.965

— 2020b. Freshwater fishing strategies in early modern Sami households. Arctic Anthropology 57(2):197-211. https://doi.org/10.3368/aa.57.2.197

Linnaeus, C. 2003. Iter Lapponicum. Lappländska resan 1732, I. Dagboken. [Expedition to Lapland 1732, I. Diaries]. Umeå: Kungl. Skytteanska Samfundet.

Lundius, N.A. 1905. Descriptio Lapponiæ [Description of Lapland]. Uppsala: Harald Wretmans tryckeri.

Lundmark, L. 1982. Uppbörd, utarmning, utveckling: Det samiska fångstsamhällets övergång till rennomadism i Lule Lappmark [Taxation, expropriation, and development: The transition of Saami hunting society to reindeer-nomadism in Lule Lappmark]. Disseration, Umeå University, Umeå, Sweden. 
2006. Samernas skatteland i Norr- och Västerbotten under 300 år [Sami taxation lands in Norrbotten and Västerbotten counties during 300 years]. Stockholm: Institutet för Rättshistorisk Forskning.

Manker, E. 1960. Fångstgropar och stalotomter [Pitfalls and stalo foundations. Stockholm: Gebers.

Marklund, B. 2015. Det milsvida folket: Skogssamernas samhälle i omvandling, 1650-1800 [The boundless forest's people: The forest Sami society in transformation 1650-1800]. Disseration, Umeå University, Umeå, Sweden.

http://umu.diva-portal.org/smash/record.jsf?pid=diva2\%3A79 8349\&dswid=-1398

McGinnis, M.D., and Ostrom, E. 2014. Social-ecological system framework: Initial changes and continuing challenges. Ecology and Society 19(2): 30.

https://doi.org/10.5751/ES-06387-190230

Mulk, I.-M. 1994. Sirkas, ett samiskt fångstsamhälle i förändring Kr.f.-1600 e.Kr. [Sirkas a Sami hunting society in transition AD 1-1600]. Disseration, Umeå University, Umeå, Sweden.

. 2005. Bosättningsmönster, vildrensjakt och tamrenskötsel i Lule lappmark - 100 e.kr-1600 e.kr [Settlement patterns, wild reindeer hunting, and reindeer husbandry in Lule lappmark district AD 100-1600]. Fra Villreinjakt til Reindrift $1: 33-59$.

Niurenius, O.P. 1905. Lappland, eller beskrivning över den nordiska trakt, som lapparne bebo i de avlägsnaste delarne af Skandien eller Sverge [Lapland or a description of the Nordic region inhabited by the Sami in the most remote parts of Scandinavia or Sweden]. Uppsala: Harald Wretmans tryckeri.

Norstedt, G. 2011. Lappskattelanden på Geddas karta: Umeå lappmark från 1671 till 1900-talets början [The taxation lands on Gedda's map: Ume lappmark from 1671 to the early twentieth century]. Umeå: Thalassa förlag.

. 2018. A land of one's own: Sami resource use in Sweden's boreal landscape under autonomous governance. Dissertation, Swedish University of Agricultural Sciences, Umeå, Sweden. https://pub.epsilon.slu.se/15451/1/norstedt_g_180502.pdf

Norstedt, G., Axelsson, A.-L., and Östlund, L. 2014. Exploring pre-colonial resource control of individual Sami households. Arctic 67(2):223-237.

https://doi.org/10.14430/arctic4389

Nyrén, U. 2012. Rätt till jakt: En studie av den Svenska jakträtten ca 1600-1789 [Game laws in Sweden: A study of hunting laws ca 1600-1789]. Dissertation, Gothenburg University, Gothenburg, Sweden.

https:/gupea.ub.gu.se/bitstream/2077/28994/2/gupea_2077_ 28994_2.pdf

Odner, K. 1983. Finner och terfinner: Etniske prosesser i det nordlige Fenno-Scandinavia [Finns (Sami) and Ter-finns: Ethnic processes in northern Fenno-Scandinavia]. Occasional Paper 9. Oslo: Department of Social Anthropology, University of Oslo.

Öhrling, S. [1773] 1970. Historisk-ekonomisk avhandling om Arjeplogs församling i Lappland [History-economic dissertation about Arjeplog's parish in Lapland]. Arjeplog: Silvermuseet.
Ostrom, E. 1990. Governing the commons: The evolution of institutions for collective action. Cambridge: Cambridge University Press.

. 2005. Understanding institutional diversity. Princeton, New Jersey: Princeton University Press.

- 2009. A general framework for analyzing sustainability of social-ecological systems. Science 325(5939):419-422. https://doi.org/10.1126/science.1172133

Päiviö, E.-L. 2017. Livelihood diversification in early modern Sami households in northern Sweden. In: Panjek, A., Larsson, J., and Mocarelli, L., eds. Integrated peasant economy in a comparative perspective, Alps, Scandinavia and beyond. Koper, Slovenia: University of Primorska Press.

Peterson, M.N. 2019. Hunting. In: Fath, B.D., ed. Encyclopedia of ecology, 2nd ed. Vol. 3. Amsterdam: Elsevier Science. $438-440$. https://doi.org/10.1016/B978-0-12-409548-9.11168-6

RA SH (Riksarkivet Svea hovrätt [National Archives of Sweden, Svea Court of Appeal). 1712-77. Rulings in Jokkmokks District Court, Sweden.

Rheen, S. 1897. En kortt relation om Lapparnes lefwarne och sedher, wijd-skiepellsser, sampt i många stycken grofwe wildfarellsser [A short story about Sami life and customs, superstitions, and in many cases severe delusions]. Uppsala: Harald Wretmans tryckeri.

Rose, C.M. 1985. Possession as the origin of property. The University of Chicago Law Review 52(1):73-88. https://doi.org/10.2307/1599571

Rydving, H. 2010. The 'bear ceremonial' and bear rituals among the Khanty and the Sami. Temenos 46(1):31-52.

https://doi.org/10.33356/temenos.6940

Sommerseth, I. 2009. Villreinfangst og tamreindrift i indre Troms: Belyst ved samiske boplasser mellom 650 og 1923 [Wild reindeer hunting and reindeer husbandry in inner Troms: Illuminated at Sami settlements between 650 AD and 1923]. Dissertation, University of Tromsø, Tromsø, Norway.

. 2011. Archeology and the debate on the transition from reindeer hunting to pastoralism. Rangifer 31(1):111-127. https://doi.org/10.7557/2.31.1.2033

Stiernman, A.A. 1747-75. Samling utaf kongl. bref,... angående Sweriges rikes commerce,...Del 1-6 [Collection of Royal letters...concerning Sweden's commerce,... part 1-6]. Stockholm: Kongl. Tryckeriet.

Tanner, V. 1929. Antropogeografiska studier inom Petsamoområdet [Anthropogeographical studies in Petsamo area]. Helsinki: Tilgmanns Tryck.

Tegengren, H. 1952. En utdöd lappkultur i Kemi lappmark: Studier i Nordfinlands kolonisationshistoria [An extinct Sami culture in Kemi lappmark district: Studies in the colonization history of Northern Finland]. Åbo: Åbo akademi.

Tornæus, J.J. 1900. Berättelse om Lapmarckerna och deras tillstånd [Description on the Sami districts and their condition]. Uppsala: Harald Wretmans tryckeri. 
Vorren, Ø. 1978. Bosetning och naturesursutntting under veidekulturen og dens differensiering [Settlement and natural resource use during fisher and hunter culture and its differentiation]. Finnmarksvidda natur-kultur. Oslo: Statens forvaltningstjeneste.

- 1980. Samisk bosetning på Nordkalotten, arealdisponering og resursutnytting i historisk-økologisk belysning [Sami settlement at the Cap of the North, land use and resource use in a historical-ecological examination]. In: Baudou, E., and Dahlstedt, K.-H., eds. Nordskandinaviens historia i tvärvetenskaplig belysning [North Scandinavian history in an interdisciplinary examination]. Umeå: Almqvist \& Wiksell. $235-261$.
1998. Villreinfangst i Varanger fram til 1600-1700 årene [Wild reindeer hunt in Varanger until the 1600s-1700s]. Nordkalott-Forlaget: Tromsø museums skrifter 28.

Wiklund, K.B., and Qvigstad, J. 1909. Dokument angående flyttlapparna, del II [Documents concerning Sami nomads, part 2]. Kristiania, Norway: Grøndahl \& Søns boktryckeri. 